\title{
Varietal and germinative characterization of Agave potatorum (Asparagaceae) seeds with different origins
}

\author{
Yolanda Donají Ortiz-Hernández'1, Germán Fernando GutiérRez- \\ Hernández ${ }^{*}$, Luis Jorge Corzo-Ríos², Elpidio García-Ramírez ${ }^{3}$, AND \\ Sabino Honorio Martínez-Tomás ${ }^{1}$
}

Botanical Sciences 96 (4): 628-639, 2018

DOI: $10.17129 /$ botsci.1914

Received:

November 17th, 2017

Accepted:

July 5th, 2018

Associated editor:

Ivón Ramírez-Morillo
${ }^{1}$ Centro Interdisciplinario de Investigación para el Desarrollo Integral Regional Unidad Oaxaca, Instituto Politécnico Nacional, Oaxaca, Mexico.

${ }^{2}$ Unidad Profesional Interdisciplinaria de Biotecnología, Instituto Politécnico Nacional, Mexico City, Mexico.

${ }^{3}$ Facultad de Química,

Universidad Nacional

Autónoma de México, Mexico City, Mexico.

* Corresponding author: ggutierrezh@ipn.mx.

This is an open access article distributed under the terms of the Creative Commons Attribution License CC BY-NC (4.0) international.

\section{Abstract}

Background: Agave potatorum reproduces mainly through seeds is widely collected for the mezcal production, and there is currently a marked decrease in their wild populations. Therefore, to contribute to its sustainable use, it is important to characterize the morphology of its seeds and to know their germinative characteristics.

Research question: Do the year and the collection site have an effect on the size, color, viability and germination capacity of Agave potatorum seeds?

Species studied: Agave potatorum Zucc.

Study site and period of research: Seeds of Agave potatorum were collected in Oaxaca, Mexico: Miahuatlán (MIAH), in 2014; Coixtlahuaca (COIX), in 2015; and Zaachila (ZAA), in 2015 and 2016.

Methods: For the seeds, we analyzed four physical descriptors, five color coordinates, and nine germination variables. We used a completely randomized design with four replications (100 seeds). An analysis of variance, a comparison of means, and a linear correlation analysis were performed.

Results: We found that the ZAA16 seeds showed the highest values $(P<0.05)$ for weight and size, and for the luminosity coordinate $\left(\mathrm{L}^{*}, 15.2\right)$. Color coordinate values revealed a black color of the seeds, which significantly diminished in luminosity with seeds age and varied with their origin. The coordinate $\mathrm{L}^{*}$ was correlated significantly with the total dry weight of seedlings and seed volume.

Conclusions: Agave potatorum seeds significantly changed their physical dimensions and germination capacity according to their origin. The luminosity of the black color of seeds decreased with seed age and was correlated with seed volume and seedling total dry weight.

Key words: Agave potatorum, seedling emergence, seed germination, tetrazolium, varietal description, viability.

\section{Resumen}

Antecedentes: El Agave potatorum se reproduce principalmente por semilla, se recolecta ampliamente para producir mezcal y sus poblaciones silvestres están reduciéndose. Por ello, para contribuir a su utilización sustentable es importante caracterizar sus semillas, en términos de morfología y características germinativas.

Pregunta: ¿El año y el sitio de colecta afectan el tamaño, el color, la viabilidad y la capacidad de germinación de las semillas de Agave potatorum?

Especie estudiada: Agave potatorum Zucc.

Sitio de estudio y fecha: Las semillas se colectaron en Oaxaca, México: Miahuatlán (MIAH), en 2014, Coixtlahuaca (COIX), en 2015) y Zaachila (ZAA), en 2015 y 2016.

Métodos: Se evaluaron cuatro descriptores físicos de semilla, cinco coordenadas de color y nueve variables de la germinación. Se empleó un diseño completamente al azar con cuatro repeticiones de 100 semillas. Los resultados se sometieron a análisis de varianza, comparación de medias (Tukey, $P<0.05)$ y correlación lineal.

Resultados: Las semillas de ZAA16 mostraron los valores más altos $(P<0.05)$ de peso, tamaño y luminosidad. Las coordenadas de color revelaron el color negro de las semillas, del cual disminuyó significativamente su luminosidad con la edad y con el área de colecta. La luminosidad de la semilla correlacionó significativamente con peso seco total de plántula y volumen de semilla.

Conclusiones: Las semillas de Agave potatorum cambiaron sus dimensiones físicas y capacidad germinativa según su origen. La luminosidad del color de las semillas disminuyó con su edad y correlacionó con volumen de semilla y peso seco total de plántula.

Palabras clave: Agave potatorum, descripción varietal, emergencia de plántulas, germinación, tetrazolio, viabilidad. 
exico possesses $90 \%$ of the agave species that exist in the world (García-Mendoza 2010). These plants have great ecological, social, cultural, and economical relevance because they supply fibers, honey, combustion and construction materials, paper, medicinal extracts, and alcoholic beverages (García-Herrera et al. 2010); in addition, some of their structures are basic components of Mexican traditional cuisine (for example, mixiotes, tamales, and Mexican barbecue). Agaves (Asparagales Link, Asparagaceae Juss., Agavoideae Herb., Agave L.; APG III 2009) are perennial plants that reach sexual maturity at approximately six years old; they bloom, bear fruits, and produce seeds only once in the lifetime, after which they start their senescence and die, a phenomenon known as semelparity (Arizaga \& Ezcurra 1995).

The Central Valleys and the Sierra Sur of Oaxaca, Mexico, constitute the mezcal region. The most used agave species are Agave angustifolia Haw., A. rhodacantha Trel., A. potatorum Zucc., A. seemanniana Jacobi, A. marmorata Roezl, A. karwinskii Zucc., A. americana L. var. americana, and A. americana var. oaxacensis Gentry. Some of these are cultivated, but collecting wild agaves remains a common practice of the traditional mezcal distillers, which induces deforestation, soil erosion, and loss of biodiversity. Agave potatorum was described by Zuccarini in 1832 (García-Mendoza 2010) and is known as tobalá, papalomé or papalometl (butterfly agave, in Nahuatl; Figures 1 and 2). It grows mainly in Pinus-Quercus forests and deciduous forests, and it is the most collected species for the production of "Tobalá" mezcal, which is appreciated for its unique characteristics such as bouquet and taste. This taxon (Figure $2 \mathrm{E}$ ) belongs to the 37 agave species used to produce mezcal, which is a distilled alcoholic beverage obtained from the sugars contained in the short and succulent stem of the plant, the popular name of which is "piña" or "heart" (Figure 2H). This is cooked (Figure 2I), ground and fermented before distillation (Figure 2J). The collection or harvest of the "piña" from the cultivated agaves is done when plants reach their maximum weight and size, at the latest; thus, the floral scape ("quiote") is removed when it is just starting to elongate $(40-60 \mathrm{~cm})$. By eliminating the inflorescence (i.e., "castrating" the agave), sexual reproduction is avoided, and this slowly

\section{Author contributions:}

Yolanda Donají OrtizHernández collected the genetic material, designed the experiment, and took the pictures.

Germán Fernando GutiérrezHernández designed and set up the experiments, organized and analyzed data, and wrote the paper.

Luis Jorge Corzo-Ríos helped carry out the physical experiments and helped write the paper.

Elpidio García-Ramírez helped carry out the physiological experiments and helped write the paper. Sabino Honorio MartínezTomás helped write the paper.

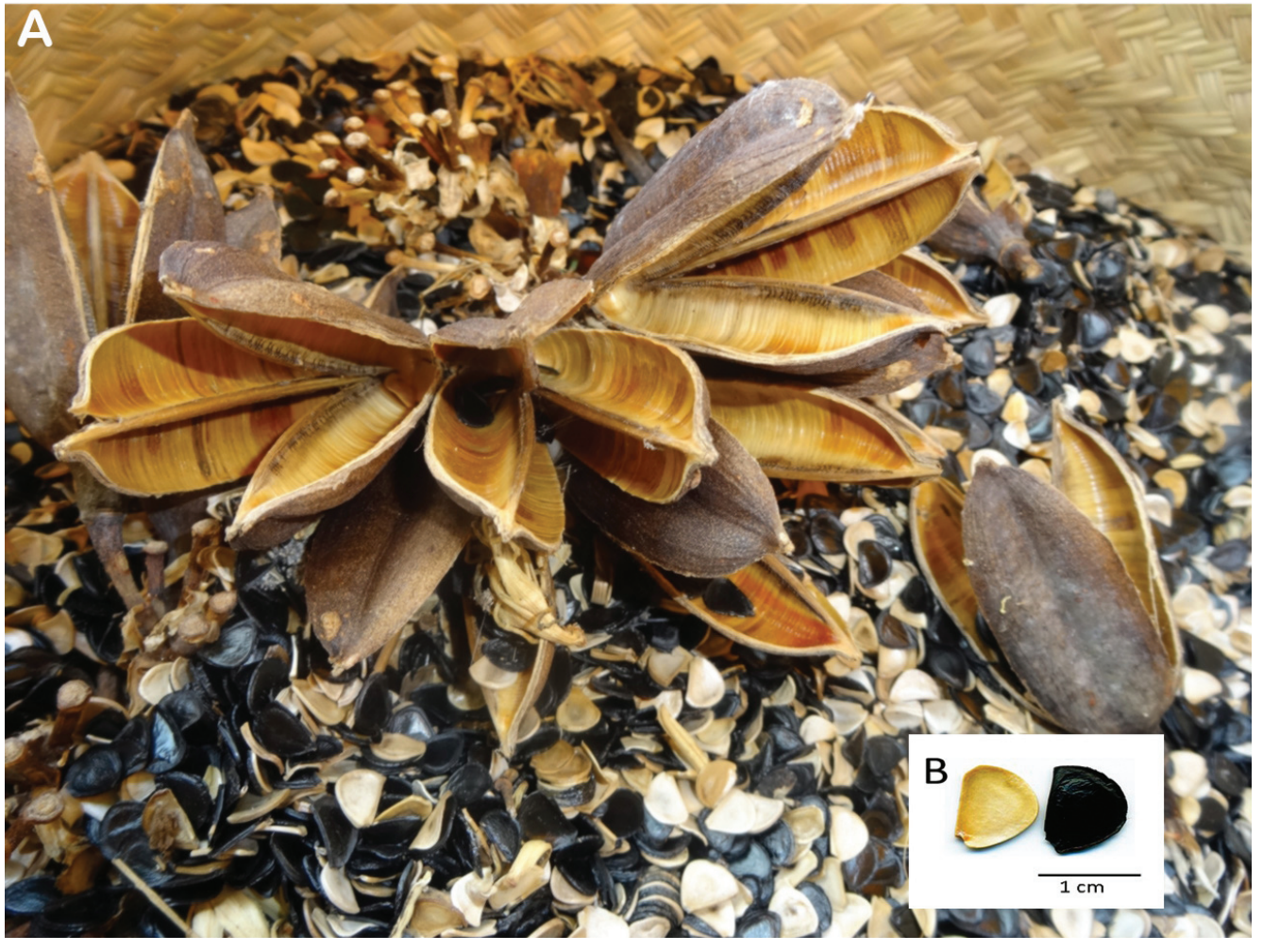

Figure 1. Agave potatorum: A) Dry capsules and seeds. B) Seeds with a white or black seed coat (Photographs by Yolanda D. Ortiz-Hernández). 


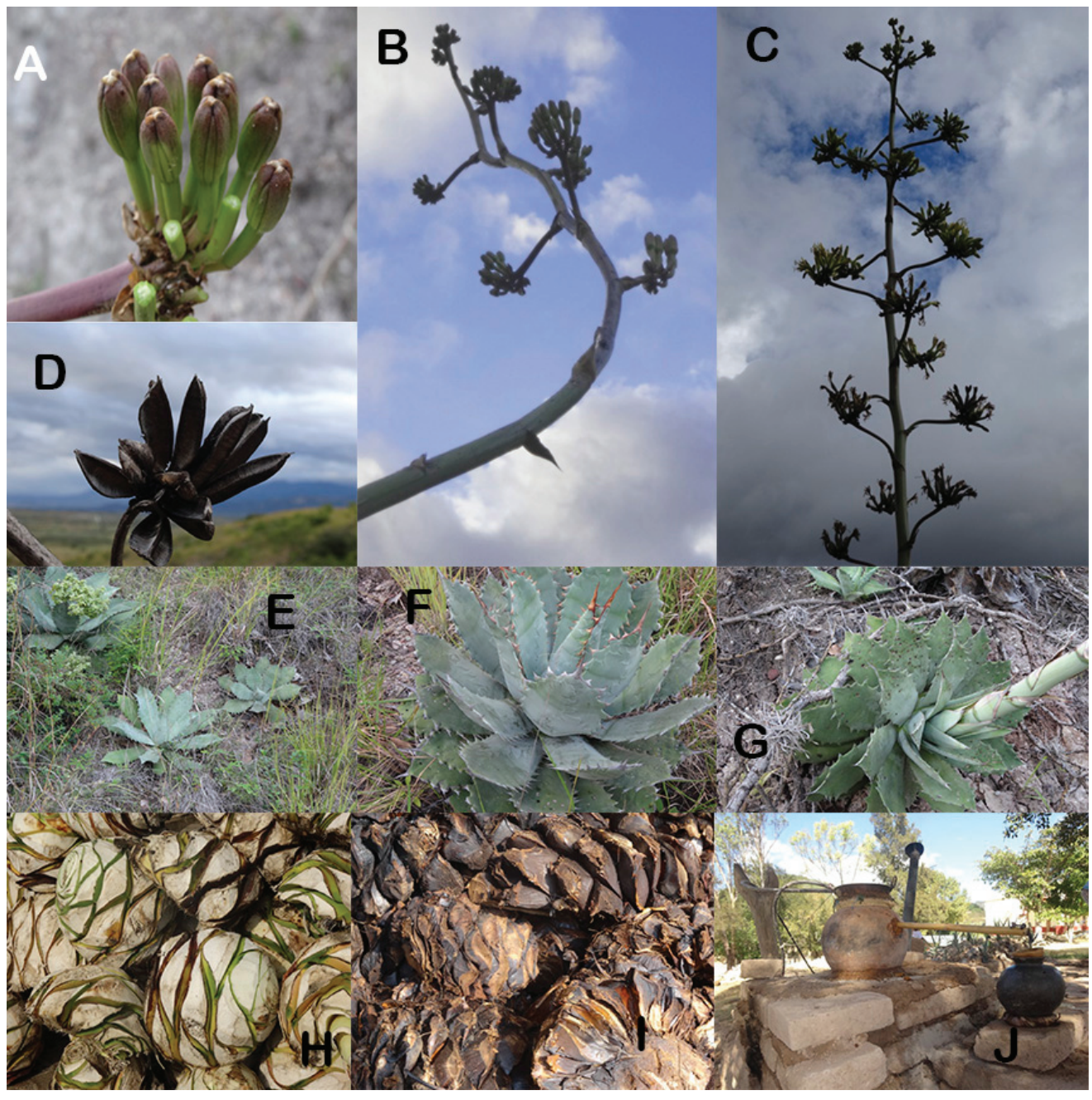

Figure 2. Agave potatorum: A) Floral buttons. B) Inflorescence (floral scape or "quiote"). C) Inflorescence with floral buttons and fruits (capsules). D) Dehiscent capsules without seeds. E) Wild plants. F) Adult plant without emission of the floral scape. G) Adult plant with emission of the floral scape. H) Agave heart (“piña”). I) Cooked “piña”. J) Mezcal traditional distiller (Photographs by Yolanda D. Ortiz-Hernández).

leads to genetic erosion and a loss of potentially valuable populations (Torres et al. 2014). The start of flowering (Figure 2F) is the phenological stage at which the stalk has accumulated the largest amount of photosynthates (glucose), which are biologically responsible for flowering (Figure 2G), fruit-bearing, and seed formation processes (Figures 2A, 2B, 2C, and 2D). When the inflorescence is cut, the photosynthates remain stored and are used to ferment the "piña" and to distill the mezcal (Figure 2J).

Wild populations of $A$. potatorum in diverse regions of Oaxaca are disappearing (RangelLanda et al. 2015) because its asexual reproduction is almost nonexistent, and there is not sustainable management (Torres et al. 2014). Seeds are the main propagation source of this species (García-Mendoza 2010), which is advantageous for genetic variability and species evolution (Cruz et al. 1985); however, this method of propagation is disrupted when processing the plants to produce mezcal, and consequently, the diversity (Delgado-Lemus et al. 2014) and survival of the butterfly agave are compromised (Enríquez del Valle 2008). Furthermore, A. potatorum seeds possess scarce viability and germination, and the seedlings produced from seeds are very heterogeneous and show slow growth (Valenzuela-Zapata 1994). It is noticeable that most of these plants also reproduce asexually through suckers and runners as well as through small 
bulbils formed in the flowering stalks (Arizaga \& Ezcurra 1995). To design new methods to reproduce these plants, it is necessary to produce a description of the different varieties in terms of characteristics of the whole plant or of its components; these characteristics could be physical, morphological, physiological, biochemical, or even molecular (Gutiérrez-Hernández et al. 2011). By the detailed characterization of a variety, it is possible to identify and to estimate the variation in descriptors among localities or years of collection; in addition, it is useful to estimate the genetic variability present in one geographical area (Gutiérrez-Hernández et al. $o p$.cit.). For the agave under study in particular, it would be useful to know its population dynamics and to control its exploitation.

To contribute to the knowledge, conservation, and sustainable use of A. potatorum, it is necessary to know the physical and physiological characteristics of its seeds as well as to associate these aspects with the origin of the seeds, i.e., their site and year of production. Regarding color characterization, the International Commission on Illumination (CIE 2004) established the coordinates $\mathrm{L}^{*}, \mathrm{a}^{*}$, and $\mathrm{b}^{*}$ for the color space. $\mathrm{L}^{*}$ corresponds to the luminosity coefficient ( $0=$ black and $100=$ white); $a^{*}$, to the colors red to purple (positive values) or green to blue (negative values); and $\mathrm{b}^{*}$, to yellow colors (positive values) or blue colors (negative values) (McGuire 1992, Padrón-Pereira et al. 2012, Alvis et al. 2017). Since coordinates a* and b* are interdependent, to make accurate color measurements, it is recommended that the chroma (c) and the degree of color saturation (h) be quantified (McGuire 1992). The first is defined as the hue (it ranges from gray to the pure color) and is calculated with the equation $c=\left(a^{* 2}+b^{* 2}\right)^{1 / 2}$, while the second is the saturation or tone angle, and it is obtained with the equation $\mathrm{h}=(\arctan$ $\left.\mathrm{b}^{*} / \mathrm{a}^{*}\right)$; this assumes a coloration according to its value, i.e., at $0^{\circ}$, red to purple; at $90^{\circ}$, yellow; at $180^{\circ}$ green to blue; and at $270^{\circ}$, blue. Viability is an indicator of the metabolic potential of the seed, is evaluated during the first hours after seed hydration and indirectly estimates the germinative potential (Copeland \& McDonald 2001). The ability of a given species to generate complete seedlings at a specific time under optimal conditions of temperature and humidity (ISTA 2015) is determined by the normal germination test (Vadillo et al. 2004).

In the present study, we assessed the germinative attributes of $A$. potatorum seeds as well as their color and dimensions; with this knowledge, we aim to develop strategies for their sustainable use. The objectives were i) To obtain the varietal description of $A$. potatorum seeds with different origins (years and collection sites) in terms of their physical dimensions and color coordinates, and ii) To determine the viability and germinative capacity of the collected seeds.

\section{Materials and methods}

Genetic material collection. We collected mature capsules of wild plants of Agave potatorum before their dehiscence, in three localities of Oaxaca State, Mexico: San Miguel Coatlán, Miahuatlán (South Sierra), in 2014; San Miguel Tulancingo, Coixtlahuaca (Mixtec region), in 2015; and San Antonio Huitepec, Zaachila (Central Valleys), in 2015 and 2016 (Table 1). Based on the sites and years of collection, we generated four groups to be assessed in the present work (Table 2). In each year, the collection period was from April to May, and the capsules were exposed freely to air for 5 days and then opened to extract and select the seeds (Figure 1A), which were packed in the carpels (Figure 1B) and had a black or white seed coat. Observation of seeds with a stereoscopic microscope (Celestron Labs S10-60) revealed that the black seeds contained an embryo and a cotyledon, and we assumed that they corresponded to the fertilized and developed ovule, in contrast to the white ones, which were empty; hence, only the black seeds were chosen for this study, and they were placed in paper bags, and stored in darkness without moisture or temperature control until used. All the experiments were carried out in the UPIBI-IPN at the Molecular Biotechnology Laboratory and at the Food Research Laboratory. For each of the evaluations, four replications of 100 seeds each were used.

Weight and dimensions of the seeds. The seeds were weighed ( $\mathrm{g}$ ) with an analytical balance (AE Adam P W 184, $0.1 \mathrm{mg}$ accuracy). We measured $(\mathrm{mm})$ with a digital vernier caliper (Mitutoyo CD-6 CSX) the larger axis (SEEDLON) and the smaller one (SEEDWID) as well as the thickness (SEEDTHI) of the seeds. 
Table 1. Characteristics of the collection sites of Agave potatorum seeds used in the study.

\begin{tabular}{|c|c|c|c|}
\hline & $\begin{array}{c}\text { San Miguel Coatlán, } \\
\text { Miahuatlán }\end{array}$ & $\begin{array}{c}\text { San Miguel Tulancingo, } \\
\text { Coixtlahuaca }\end{array}$ & $\begin{array}{c}\text { San Antonio Huitepec, } \\
\text { Zaachila }\end{array}$ \\
\hline Region & South Sierra & Mixtec & Central Valleys \\
\hline Climate & $(A) C(w 2)$ & Cwo & Cwb \\
\hline $\begin{array}{l}\text { Average annual } \\
\text { temperature }\left({ }^{\circ} \mathrm{C}\right)\end{array}$ & 21.0 & 15.3 & 16.3 \\
\hline Annual rainfall $(\mathrm{mm})$ & 1,100 & 545 & 1,042 \\
\hline Altitude (m a.s.I.) & 1,658 & 2,249 & 2,313 \\
\hline North latitude & $16^{\circ} 15^{\prime} 8^{\prime \prime}$ & $17^{\circ} 45^{\prime} 00^{\prime \prime}$ & $16^{\circ} 94^{\prime} 14^{\prime \prime}$ \\
\hline West longitude & $96^{\circ} 40^{\prime} 53^{\prime \prime}$ & $97^{\circ} 25^{\prime} 59^{\prime \prime}$ & $97^{\circ} 15^{\prime} 31^{\prime \prime}$ \\
\hline Vegetation & $\begin{array}{l}\text { Pinus-Quercus forests, } \\
\text { and xerophytic shrubs }\end{array}$ & $\begin{array}{l}\text { Pinus-Quercus forests } \\
\text { and xerophytic shrubs }\end{array}$ & $\begin{array}{l}\text { Pinus-Quercus forests } \\
\text { and xerophytic shrubs }\end{array}$ \\
\hline
\end{tabular}

Source: http://es.climate-data/location

Color space coordinates of the seeds. We obtained images of the collected seeds and digitized them with a scanner. We utilized Adobe Photoshop CS3 software (Adobe Systems Inc. USA) for image analysis. We obtained the color parameters of the seeds, namely $L^{*}, a^{*}, b^{*}, c$, and $h$ (McGuire 1992, Padrón-Pereira et al. 2012, Alvis et al. 2017). For each group, we established four measuring points on the superior and posterior sides of the seed, and obtained their average. For this analysis, we did not include the COIX15 group.

Seed viability. We used the tetrazolium test (Fragoso-Pérez et al. 2006). For this test, seeds were hydrated in distilled water for $24 \mathrm{~h}$; afterwards, with a scalpel, a longitudinal and perpendicular cut with respect to the larger axis of the seed was made, aiming to cut the cotyledon and embryo in half to expose the inner tissues of the embryo to the tetrazolium solution.

The seed halves, with the exposed embryo, were deposited in Petri dishes with $10 \mathrm{~mL}$ of the tetrazolium solution $\left(1 \%, \mathrm{w} / \mathrm{v}\right.$ ) and incubated at $25 \pm 2{ }^{\circ} \mathrm{C}$ (Meditech MTAC26) for $12 \mathrm{~h}$ in darkness for stain development (Ramírez-Tobías et al. 2016). After this time, seeds were observed using a stereoscopic microscope (Celestron Labs S10-60), and we evaluated the location and the intensity of the developed color (red compound named formazan) in each embryonic axis. We assigned each dyed seed half to one of the 16 cases of staining patterns for monocotyledonous seeds developed by Delouche et al. (1971); then, we calculated the proportion (\%) of viable (VIA) and nonviable (NVIA) seeds (Ramírez-Tobías et al. 2016).

Germination and seedling emergence. For these variables, seeds were sown in a seedbed with sterile substrate (peat moss) at a $2 \mathrm{~cm}$ depth and incubated for 15 days in a germination chamber (Meditech MTAC26) at $25 \pm 2{ }^{\circ} \mathrm{C}$ with constant white light. Seedlings started to emerge 4 days after sowing (DAS); this variable was assessed every $24 \mathrm{~h}$, and the index of emergence velocity was estimated using the following equation: $E V I=\sum_{i=1}^{n} \frac{X_{i}}{N_{i}}$ where $\mathrm{X}_{\mathrm{i}}=$ number of seedlings emerged per day, $\mathrm{N}_{\mathrm{i}}=\mathrm{i}$ DAS, and $\mathrm{i}$ corresponds to the number of days since the start of seedling emergence (Maguire 1962).

Table 2. Description of treatments and origins (site and year of collection) of Agave potatorum seeds under study.

\begin{tabular}{lcc} 
Treatment & Origin & Year \\
\hline MIAH14 & San Miguel Coatlán, Miahuatlán & 2014 \\
COIX15 & San Miguel Tulancingo, Coixtlahuaca & 2015 \\
ZAA15 & San Antonio Huitepec, Zaachila & 2015 \\
ZAA16 & San Antonio Huitepec, Zaachila & 2016 \\
\hline
\end{tabular}


After 15 DAS, we counted (\%) the total emergence of seedlings (TE), and we extracted the seedlings and measured $(\mathrm{mm})$ with a digital vernier caliper (Mitutoyo CD-6 CSX) the length of the radicle (RADL) and the plumule (PLULON) and the total length (TL); lastly, these structures were dried at $65^{\circ} \mathrm{C}$ (RIOSSA H-102) for $72 \mathrm{~h}$, and their respective dry weights (mg) were determined (RADW, PLUDW, and TDW) (Gutiérrez-Hernández et al. 2011) with an analytical balance (AE Adam PW 184; accuracy of $0.1 \mathrm{mg}$ ).

Statistical analysis. A completely randomized design was used in all experiments, with four replications of 100 seeds each. Comparison of the means of treatments was performed by Tukey's HSD (honest significant difference) test $(P<0.05)$. Evaluation of associations among variables was made with a correlation analysis $(P<0.01$ and $P<0.05)$. Statistical processing of data was accomplished with SAS software (SAS 2002).

\section{Results}

We characterized seeds of Agave potatorum with different origins (site and year of collection) in terms of their dimensions, color, viability, germination, and emergence of seedlings, and a statistical analysis of the data was performed. The analysis of variance revealed significant differences $(\mathrm{P}<0.01)$ in all the germinative variables and the varietal descriptors, except for the color parameters $\mathrm{a}^{*}, \mathrm{~b}^{*}, \mathrm{c}$ and $\mathrm{h}$ (Table 3 ). Thus, we proceeded to examine specifically the differences for each significant variable by Tukey's test (Tables 4, 5, and 6).

Weight and dimensions of the seeds. The ZAA16 group showed the highest values $(P<0.05)$ for the dimensions of the seeds (W100, SEEDLON, SEEDWID, and SEEDTHI). This group was followed by ZAA15, COIX15, and MIAH14; the last group had the smallest physical proportions (Table 4). The physical dimensions of seeds collected in the Zaachila location significantly changed $(P<0.05)$ from 2015 to 2016, which suggested high genetic variability in $A$. potatorum in this collection site because the seeds were collected at approximately the same places.

Color space coordinates of the seeds. We visually observed that the seeds were black. The color coordinates $\mathrm{a}^{*}, \mathrm{~b}^{*}, \mathrm{c}$, and $\mathrm{h}$ did not vary among origins. The values of $\mathrm{a}^{*}$ were low and positive, those of $b^{*}$ were close to zero and positive, the chroma (c) exhibited low values, and the coordinate $\mathrm{h}$ had values close to 100 (Table 5). Only the luminosity coordinate ( $\left.\mathrm{L}^{*}\right)$ significantly changed $(P<0.05)$ among years and geographical collection areas. The ZAA16 seeds had the highest value $(P<0.05)$ of $L^{*}(15.2)$, followed by those from ZAA15 (11.0) and then MIAH14 (9.6). We noticed that the seeds lost their brightness as their age increased.

Germination and seedling emergence. The VIA and TE values were statistically the same for ZAA16, ZAA15, and COIX15 seeds (Table 6). The physiological performance of the MIAH14 group was the lowest (Tables 6 and 7) because these seeds had the lowest capacity to germinate and for seedling emergence $(P<0.05)$. In contrast, the ZAA16, ZAA15, and COIX15 groups stood out for their high and consistent performance, as they reached the best values $(P<0.05)$ in VIA, TE, RADL, PLULON, and TL, whereas for the other variables (EVI, RADW, PLUDW, and TDW), they alternated their position in the first two significance levels. Thus, in our study, the seeds with the largest dimensions (MIAH14) did not have the greatest physiological performance.

Correlations. The associations among the measured physiological characteristics (Table 8 and 9) showed that seeds with higher metabolic potential (VIA) had the best seedling performance (TE), were larger (RADL, PLULON, and TL) and had a higher biomass (RADW, PLUDW, and TDW), with a correlation coefficient of $0.8^{* *}$ in all cases. For the correlations among physical descriptors (Table 10), the weight of the seeds (W100) increased $\left(0.8^{* *}\right)$ according to the seed dimensions (SEEDLON, SEEDWID, and SEEDTHI), whereas the length of the seed (SEEDLON) was correlated with SEEDWID $\left(0.6^{* *}\right)$ and SEEDTHI $\left(0.8^{* *}\right)$. The thickness of the seed (SEEDTHI) was inversely correlated with EVI $\left(-0.6^{* *}\right)$ and TE $\left(-0.6^{* *}\right)$. Regarding the color 
Table 3. Mean squares and statistical significance of the assessed variables in the Agave potatorum seeds under study.

\begin{tabular}{|c|c|c|}
\hline Variable & Mean squares & Significance \\
\hline VIA & $1,244.5$ & $* *$ \\
\hline NVIA & $1,244.5$ & $* *$ \\
\hline EVI & 10.3 & $* *$ \\
\hline $\mathrm{TE}$ & $6,648.0$ & $* *$ \\
\hline RADL & 132.9 & $* *$ \\
\hline PLUL & 211.0 & $* *$ \\
\hline TL & 677.6 & $* *$ \\
\hline RADW & 0.0002 & $* *$ \\
\hline PLUDW & 0.0059 & $* *$ \\
\hline TDW & 0.0083 & $* *$ \\
\hline W100 & 0.1117 & $* *$ \\
\hline SEEDLON & 0.5930 & $* *$ \\
\hline SEEDWID & 0.5491 & $* *$ \\
\hline SEEDTHI & 0.0094 & $* *$ \\
\hline$L^{*}$ & 162.9 & $* *$ \\
\hline$a^{*}$ & 13.8 & ns \\
\hline$b^{*}$ & 0.86 & $\mathrm{~ns}$ \\
\hline C & 14.96 & $\mathrm{~ns}$ \\
\hline $\mathrm{h}$ & $9,310.99$ & ns \\
\hline
\end{tabular}

** = Highly significant $(P<0.01), \mathrm{ns}=$ Not significant.

coordinates (Table 11$), \mathrm{L}^{*}$ was correlated significantly $\left(0.8^{* *}\right)$ with seed weight (W100) and with the dimensions of the seed (SEEDLON, 0.74**; SEEDWID, $0.8^{* *}$; and SEEDTHI, 0.7**), whereas $\mathrm{a}^{*}$ and $\mathrm{c}$ were only correlated with the latter, and $\mathrm{h}$ was only correlated with SEEDTHI. The color coordinates revealed that, with an increase in the coordinates a (dark red to light green) and c (color hue), VIA ( $\left.-0.5^{* *}\right)$ decreased, and NVIA $\left(0.5^{* *}\right)$ increased.

\section{Discussion}

Our results showed a close relationship between the origin and the physical and physiological characteristics of $A$. potatorum seeds. For example, ZAA16 and ZAA15 seeds consistently had the highest seed dimensions and weight, while ZAA16 seeds also exhibited the best values $(P<$ $0.05)$ for all the germinative variables $(P<0.05)$ (Table 4). Thus, these results could be attributed to the greater rainfall in this location, its temperate climate, and the presence of oak forest,

Table 4. Comparison of means obtained for the physical dimensions of the Agave potatorum seeds under study.

\begin{tabular}{lcccc} 
Treatment & W100 & SEEDLON & SEEDWID & SEEDTHI \\
\hline MIAH14 & $0.9 \mathrm{~b}$ & $7.7 \mathrm{a}$ & $4.9 \mathrm{c}$ & $0.6 \mathrm{a}$ \\
COIX15 & $0.7 \mathrm{c}$ & $7.0 \mathrm{~b}$ & $4.8 \mathrm{c}$ & $0.5 \mathrm{~b}$ \\
ZAA15 & $0.8 \mathrm{~b}$ & $7.3 \mathrm{~b}$ & $5.3 \mathrm{~b}$ & $0.5 \mathrm{~b}$ \\
ZAA16 & $1.1 \mathrm{a}$ & $7.8 \mathrm{a}$ & $5.6 \mathrm{a}$ & $0.6 \mathrm{a}$ \\
HSD & 0.1 & 0.4 & 0.3 & 0.04 \\
\hline
\end{tabular}

In columns, the means with the same letter are statistically equal $(P<0.05), \mathrm{HSD}=$ Honest significant difference. 
Table 5. Comparison of means obtained for the color coordinates of the Agave potatorum seeds under study.

\begin{tabular}{lccccc} 
Treatment & $\begin{array}{c}\text { Luminosity } \\
\mathrm{L}^{*}\end{array}$ & $\begin{array}{c}\text { Colors red to } \\
\text { green } \\
\mathrm{a}^{*}\end{array}$ & $\begin{array}{c}\text { Colors yellow } \\
\text { to blue } \\
\mathrm{b}^{*}\end{array}$ & $\begin{array}{c}\text { Chroma } \\
\mathrm{c}\end{array}$ & $\begin{array}{c}\text { Saturation } \\
\mathrm{h}\end{array}$ \\
\hline MIAH14 & $9.6 \mathrm{~b}$ & $4.0 \mathrm{a}$ & $0.2 \mathrm{a}$ & $4.1 \mathrm{a}$ & $91.4 \mathrm{a}$ \\
COIX15 & - & - & - & - & - \\
ZAA15 & $11.0 \mathrm{~b}$ & $4.1 \mathrm{a}$ & $1.1 \mathrm{a}$ & $4.3 \mathrm{a}$ & $101.7 \mathrm{a}$ \\
ZAA16 & $15.2 \mathrm{a}$ & $3.1 \mathrm{a}$ & $0.2 \mathrm{a}$ & $3.2 \mathrm{a}$ & $95.5 \mathrm{a}$ \\
HSD & 1.9 & 1.6 & 1.8 & 1.6 & 304.6
\end{tabular}

In columns, the means with the same letter are statistically equal $(P<0.05), \mathrm{HSD}=$ Honest significant difference.

Table 6. Comparison of means obtained for the germination variables of Agave potatorum seeds under study.

\begin{tabular}{lllll} 
Treatment & VIA & NVIA & EVI & TE \\
\hline MIAH14 & $7 \mathrm{~b}$ & $93 \mathrm{a}$ & $0.1 \mathrm{c}$ & $4 \mathrm{~b}$ \\
COIX15 & $47 \mathrm{a}$ & $53 \mathrm{~b}$ & $3.3 \mathrm{ab}$ & $82 \mathrm{a}$ \\
ZAA15 & $37 \mathrm{a}$ & $63 \mathrm{~b}$ & $3.6 \mathrm{a}$ & $89 \mathrm{a}$ \\
ZAA16 & $39 \mathrm{a}$ & $61 \mathrm{~b}$ & $3.1 \mathrm{~b}$ & $85 \mathrm{a}$ \\
HSD & 20.7 & 20.6 & 0.49 & 12.5
\end{tabular}

In columns, means with the same letter are statistically equal $(P<0.05), \mathrm{HSD}=$ Honest significant difference.

which is associated with deep soils (Table 1). Conversely, seeds from Miahuatlán (MIAH14), a temperate zone with high rainfall, were the longest (SEEDLON) and thickest (SEEDTHI), but their weight (W100) was intermediate, and their width (SEEDWID) was the lowest. It is likely that there was genotypic variation in the seeds in their response to the environment. Since all the physical and physiological variables were significantly different $(P<0.05)$ according to their origin (Table 4), all of them could be specific for each locality; in addition, this would indicate genetic differentiation among collection sites (Garrido et al. 2005), and this finding could also be useful for the varietal description of A. potatorum. However, these descriptors varied significantly $(P<0.05)$ from 2015 to 2016 in Zaachila; hence, a larger number of samples should be collected in this location to better estimate the genetic variability of A. potatorum, and molecular studies of diversity are also required.

In terms of the efficiency of seedling emergence (EVI), the COIX15 and ZAA15 groups performed the best $(P<0.05)$; this behavior could also be attributed to the temperate climate of

Table 7. Comparison of means obtained for the germination variables of Agave potatorum seeds under study.

\begin{tabular}{lcccccc} 
Treatment & RADL & PLUL & TL & RADW & PLUDW & TDW \\
\hline MIAH14 & $0.9 \mathrm{~b}$ & $1.0 \mathrm{~b}$ & $1.9 \mathrm{~b}$ & $0.00 \mathrm{c}$ & $0.00 \mathrm{c}$ & $0.00 \mathrm{c}$ \\
COIX15 & $11.4 \mathrm{a}$ & $14.7 \mathrm{a}$ & $26.2 \mathrm{a}$ & $0.01 \mathrm{ab}$ & $0.05 \mathrm{~b}$ & $0.08 \mathrm{~b}$ \\
ZAA15 & $10.2 \mathrm{a}$ & $13.8 \mathrm{a}$ & $23.9 \mathrm{a}$ & $0.01 \mathrm{bc}$ & $0.07 \mathrm{~b}$ & $0.06 \mathrm{~b}$ \\
ZAA16 & $14.1 \mathrm{a}$ & $17.2 \mathrm{a}$ & $31.4 \mathrm{a}$ & $0.02 \mathrm{a}$ & $0.09 \mathrm{a}$ & $0.11 \mathrm{a}$ \\
HSD & 4.1 & 4.3 & 8.4 & 0.01 & 0.02 & 0.03 \\
\hline
\end{tabular}

In columns, means with the same letter are statistically equal $(P<0.05), \mathrm{HSD}=$ Honest significant difference. 


\begin{tabular}{|c|c|c|c|c|c|c|c|}
\hline Variable & VIA & NVIA & EVI & TE & RADL & PLUL & $\mathrm{TL}$ \\
\hline VIA & 1 & $\begin{array}{c}0.5 \\
\text { ns }\end{array}$ & $\begin{array}{l}0.8 \\
* *\end{array}$ & $\begin{array}{c}0.8 \\
* *\end{array}$ & $\begin{array}{c}0.8 \\
* *\end{array}$ & $\begin{array}{c}0.8 \\
* *\end{array}$ & $\begin{array}{l}0.8 \\
* *\end{array}$ \\
\hline NVIA & & 1 & $\begin{array}{c}-0.8 \\
* *\end{array}$ & $\begin{array}{c}-0.8 \\
* *\end{array}$ & $\begin{array}{c}-0.8 \\
* *\end{array}$ & $\begin{array}{c}-0.8 \\
* *\end{array}$ & $\begin{array}{c}-0.8 \\
* *\end{array}$ \\
\hline EVI & & & 1 & $\begin{array}{c}0.99 \\
* *\end{array}$ & $\begin{array}{c}0.9 \\
* *\end{array}$ & $\begin{array}{c}0.9 \\
* *\end{array}$ & $\begin{array}{c}0.9 \\
* *\end{array}$ \\
\hline TE & & & & 1 & $\begin{array}{c}0.9 \\
* *\end{array}$ & $\begin{array}{c}0.9 \\
* *\end{array}$ & $\begin{array}{c}0.9 \\
* *\end{array}$ \\
\hline RADL & & & & & 1 & $\begin{array}{c}0.99 \\
* *\end{array}$ & $\begin{array}{c}0.99 \\
* *\end{array}$ \\
\hline PLUL & & & & & & 1 & $\begin{array}{c}0.99 \\
* *\end{array}$ \\
\hline TL & & & & & & & 1 \\
\hline
\end{tabular}

both collection sites, in which the plants have to emerge faster to take advantage of precipitation and avoid frosts, particularly in Coixtlahuaca due to its reduced precipitation and lower average annual temperature (Table 1).

We expected that the seeds collected in Miahuatlán (MIAH14), which has a transitional climate and higher temperature and precipitation than the other localities, the SEEDLON and SEEDTHI dimensions of which were the highest, would have a higher metabolic rate and accumulate more biomass, but their physiological response was the lowest. This result could be explained by the greater age of the seeds, which might have depleted their metabolic potential (Marcos-Filho 2015), especially if they were recalcitrant (Willan 1991) and had a high content

\begin{tabular}{|c|c|c|c|}
\hline Variable & RADW & PLUDW & TDW \\
\hline VIA & $\begin{array}{l}0.7 \\
* *\end{array}$ & $\begin{array}{c}0.8 \\
* *\end{array}$ & $\begin{array}{c}0.8 \\
* *\end{array}$ \\
\hline NVIA & $\begin{array}{c}-0.7 \\
* *\end{array}$ & $\begin{array}{c}-0.8 \\
* *\end{array}$ & $\begin{array}{c}-0.8 \\
* *\end{array}$ \\
\hline EVI & $\begin{array}{l}0.7 \\
* *\end{array}$ & $\begin{array}{l}0.8 \\
* *\end{array}$ & $\begin{array}{l}0.8 \\
* *\end{array}$ \\
\hline TE & $\begin{array}{l}0.7 \\
* *\end{array}$ & $\begin{array}{l}0.9 \\
* *\end{array}$ & $\begin{array}{l}0.8 \\
* *\end{array}$ \\
\hline RADL & $\begin{array}{c}0.9 \\
* *\end{array}$ & $\begin{array}{c}0.95 \\
* *\end{array}$ & $\begin{array}{c}0.9 \\
* *\end{array}$ \\
\hline PLUL & $\begin{array}{c}0.9 \\
* *\end{array}$ & $\begin{array}{l}0.9 \\
* *\end{array}$ & $\begin{array}{c}0.9 \\
* *\end{array}$ \\
\hline TL & $\begin{array}{c}0.9 \\
* *\end{array}$ & $\begin{array}{c}0.95 \\
* *\end{array}$ & $\begin{array}{c}0.9 \\
* *\end{array}$ \\
\hline RADW & 1 & $\begin{array}{c}0.9 \\
* *\end{array}$ & $\begin{array}{l}0.9 \\
* *\end{array}$ \\
\hline PLUDW & & 1 & $\begin{array}{c}0.99 \\
* *\end{array}$ \\
\hline TDW & & & 1 \\
\hline
\end{tabular}

${ }^{* *}=$ Highly significant $(\mathrm{P} \leq 0.01), \mathrm{ns}=$ Not significant. 
Table 10. Linear correlation coefficients among the variables assessed in the Agave potatorum seeds under study.

\begin{tabular}{lcccc} 
Variable & W100 & SEEDLON & SEEDWID & SEEDTHI \\
\hline VIA & $-0.0 \mathrm{~ns}$ & $-0.5 \mathrm{~ns}$ & $0.2 \mathrm{~ns}$ & $-0.5 \mathrm{~ns}$ \\
NVIA & $0.0 \mathrm{~ns}$ & $0.5 \mathrm{~ns}$ & $-0.2 \mathrm{~ns}$ & $0.5 \mathrm{~ns}$ \\
EVI & $0.1 \mathrm{~ns}$ & $-0.4 \mathrm{~ns}$ & $0.4 \mathrm{~ns}$ & $-0.6^{* *}$ \\
TE & $0.0 \mathrm{~ns}$ & $-0.4 \mathrm{~ns}$ & $0.4 \mathrm{~ns}$ & $-0.6^{*}$ \\
RADL & $0.2 \mathrm{~ns}$ & $-0.2 \mathrm{~ns}$ & $0.4 \mathrm{~ns}$ & $-0.4 \mathrm{~ns}$ \\
PLUL & $0.2 \mathrm{~ns}$ & $-0.3 \mathrm{~ns}$ & $0.4 \mathrm{~ns}$ & $-0.4 \mathrm{~ns}$ \\
TL & $0.2 \mathrm{~ns}$ & $-0.3 \mathrm{~ns}$ & $0.4 \mathrm{~ns}$ & $-0.4 \mathrm{~ns}$ \\
RADW & $0.4 \mathrm{~ns}$ & $-0.1 \mathrm{~ns}$ & $0.4 \mathrm{~ns}$ & $-0.1 \mathrm{~ns}$ \\
PLUDW & $0.3 \mathrm{~ns}$ & $-0.1 \mathrm{~ns}$ & $0.5 \mathrm{~ns}$ & $-0.3 \mathrm{~ns}$ \\
TDW & $0.3 \mathrm{~ns}$ & $-0.1 \mathrm{~ns}$ & $0.5 \mathrm{~ns}$ & $-0.3 \mathrm{~ns}$ \\
W100 & 1 & $0.8 * *$ & $0.8 * *$ & $0.8^{* *}$ \\
SEEDLON & & 1 & $0.6 * *$ & $0.8 * *$ \\
SEEDWID & & & 1 & $0.3 \mathrm{~ns}$ \\
SEEDTHI & & & 1 \\
\hline
\end{tabular}

${ }^{*}=$ Significant $(P \leq 0.05),{ }^{* *}=$ Highly significant $(P \leq 0.01), \mathrm{ns}=$ Not significant.

of lipids, which is already being studied by our research team. It should be noted that both the emergence and ability to elongate and accumulate biomass of seedlings are relevant to the survival of the species, particularly in the wild species A. potatorum because it increasingly has

\begin{tabular}{|c|c|c|c|c|c|}
\hline Variable & $L^{*}$ & $a^{*}$ & $b^{*}$ & $\mathrm{C}$ & $\mathrm{h}$ \\
\hline VIA & $-0.2 \mathrm{~ns}$ & $-0.5^{*}$ & $0.2 \mathrm{~ns}$ & $-0.5 *$ & $-0.3 \mathrm{~ns}$ \\
\hline NVIA & $0.2 \mathrm{~ns}$ & $0.5 *$ & $-0.2 \mathrm{~ns}$ & $0.5 *$ & $0.3 \mathrm{~ns}$ \\
\hline EVI & $-0.1 \mathrm{~ns}$ & $-0.4 \mathrm{~ns}$ & $0.2 \mathrm{~ns}$ & $-0.3 \mathrm{~ns}$ & $-0.1 \mathrm{~ns}$ \\
\hline $\mathrm{TE}$ & $-0.0 \mathrm{~ns}$ & $-0.3 \mathrm{~ns}$ & $0.2 \mathrm{~ns}$ & $-0.3 \mathrm{~ns}$ & $-0.1 \mathrm{~ns}$ \\
\hline RADL & $0.1 \mathrm{~ns}$ & $-0.4 \mathrm{~ns}$ & $-0.1 \mathrm{~ns}$ & $-0.4 \mathrm{~ns}$ & $-0.4 \mathrm{~ns}$ \\
\hline PLUL & $0.1 \mathrm{~ns}$ & $-0.4 \mathrm{~ns}$ & $-0.0 \mathrm{~ns}$ & $-0.4 \mathrm{~ns}$ & $-0.0 \mathrm{~ns}$ \\
\hline TL & $0.1 \mathrm{~ns}$ & $-0.4 \mathrm{~ns}$ & $-0.0 \mathrm{~ns}$ & $-0.4 \mathrm{~ns}$ & $-0.0 \mathrm{~ns}$ \\
\hline RADW & $0.2 \mathrm{~ns}$ & $-0.5 \mathrm{~ns}$ & $-0.1 \mathrm{~ns}$ & $-0.5 \mathrm{~ns}$ & $-0.2 \mathrm{~ns}$ \\
\hline PLUDW & $0.1 \mathrm{~ns}$ & $-0.5 \mathrm{~ns}$ & $-0.1 \mathrm{~ns}$ & $-0.5 \mathrm{~ns}$ & $-0.1 \mathrm{~ns}$ \\
\hline TDW & $0.1 \mathrm{~ns}$ & $0.5 \mathrm{~ns}$ & $-0.1 \mathrm{~ns}$ & $-0.5 \mathrm{~ns}$ & $-0.1 \mathrm{~ns}$ \\
\hline W100 & $0.8^{* *}$ & $0.4 \mathrm{~ns}$ & $-0.0 \mathrm{~ns}$ & $0.4 \mathrm{~ns}$ & $0.2 \mathrm{~ns}$ \\
\hline SEEDLON & $0.7^{* *}$ & $0.6 *$ & $0.1 \mathrm{~ns}$ & $0.6^{* *}$ & $0.1 \mathrm{~ns}$ \\
\hline SEEDWID & $0.8^{* *}$ & $0.5 *$ & $0.3 \mathrm{~ns}$ & $0.5 *$ & $0.2 \mathrm{~ns}$ \\
\hline SEEDTHI & $0.7^{* *}$ & $0.6 *$ & $-0.1 \mathrm{~ns}$ & $0.6^{*}$ & $0.3 *$ \\
\hline$L^{*}$ & 1 & $0.7^{* *}$ & $0.1 \mathrm{~ns}$ & $0.7^{* *}$ & $0.3 \mathrm{~ns}$ \\
\hline$a^{*}$ & & 1 & $0.4 \mathrm{~ns}$ & $0.1^{* *}$ & $0.1 \mathrm{~ns}$ \\
\hline$b^{*}$ & & & 1 & $0.4 \mathrm{~ns}$ & $-0.6^{* *}$ \\
\hline c & & & & 1 & $0.1 \mathrm{~ns}$ \\
\hline $\mathrm{h}$ & & & & & 1 \\
\hline
\end{tabular}


to develop in marginal areas (Torres et al., 2014) of the geographic area known as the mezcal region in Oaxaca, Mexico. The viability of the seeds (VIA) of all origins was low, as also reported by Valenzuela-Zapata (1994), but the emergence of seedlings in terms of speed (EVI) and quantity (TE) was high (Table 6), that is, a high proportion of viable seeds emerged rapidly for all origins, except MIAH14, the seeds of which could have been aged.

The color coordinates converged on the black color as follows: the coordinate $\mathrm{a}^{*}$ values were low and positive (corresponding to a purple-red color), those of $\mathrm{b}^{*}$ were close to zero and positive (blue), c exhibited low values (gray zone), and h had values close to 100 (green color with a high content of gray) (McGuire 1992, Padrón-Pereira et al. 2012, Alvis et al. 2017). Therefore, the origin of a seed did not affect its color, which was invariably black. Only the $\mathrm{L}^{*}$ coordinate values were significantly reduced with the age of the seeds; this indicated that the seed coat lost its luminosity (brightness) with time, a feature that could be a quantitative indicator of seed viability, as it does not depend on the collection site. It is possible that the luminosity of seeds was related to fat content, which when degraded, causes both a loss of brightness of the seed coat and a reduction in the germinative potential of the seed. As the values of the coordinates a* and $\mathrm{c}$ increased, VIA decreased and NVIA increased, implying that when the color of the seeds became less gray (McGuire 1992, Padrón-Pereira et al. 2012, Alvis et al. 2017), the viability of the seeds was reduced. In addition, the $\mathrm{L}^{*}$ coordinate was correlated significantly with seedling total dry weight and seed volume; consequently, the highest luminosity corresponded to the seeds with the best germinative capacity and the highest volume and weight.

The correlation analysis showed that a higher metabolic potential (VIA) corresponded to the greatest establishment of seedlings (TE), which were larger (RADL, PLULON, and TL) and had a high biomass (RADW, PLUDW, and TDW) (Gutiérrez-Hernández et al. 2011). Moreover, the seed weight (W100) increased similarly to the seed dimensions (SEEDLON, SEEDWID, and SEEDTHI), which confirmed that seeds with a higher volume were heavier and, in turn, had a higher capacity to emerge quickly and at a high proportion. Additionally, the SEEDTHI was inversely correlated with EVI and TE, indicating that the increase in the width of the seeds was not favorable for the rapid emergence of many seedlings; nevertheless, SEEDTHI was also associated with SEEDLON $\left(0.8^{* *}\right)$ and W100 $\left(0.8^{* *}\right)$, two components previously identified (Table 6) as determinants of the physiological capacity of the seeds. Therefore, the behavior of SEEDTHI must be analyzed together with the other components of physiological performance because seeds with a greater longitude accumulated more reserves, and this allowed them to germinate faster and at a higher proportion.

Here, we showed that the size, weight, brightness and germinative performance of seeds of A. potatorum changed significantly among collection sites, and there were genotypic effects that showed genetic variation among origins and within the Zaachila origin. This diversity is probably due to the sexual recombination inherent in seed formation (Cruz et al. 1985) and is favorable for the survival of the species under study. The seeds of this agave species did not show problems of germination or establishment of seedlings. They should only be sown shortly after they reach physiological maturity; thus, the recent decrease in the populations of this species (Rangel-Landa et al. 2015) can be attributed to the intense collection that is carried out in the mezcal region in Oaxaca.

\section{Literature cited}

Alvis A, Romero P, Granados C, Torrenegra M, Pájaro-Castro N. 2017. Evaluación del color, las propiedades texturales y sensoriales de salchicha elaborada con carne de babilla (Caiman Crocodilus Fuscus). Revista Chilena de Nutrición 44: 89-94. DOI: https://doi.org/10.4067/S0717-75182017000100012

APG III (Angiosperm Phylogeny Group). 2009. An update of the Angiosperm phylogeny group classification for the orders and families of flowering plants: APG III. Botanical Journal of the Linnean Society 161: 105-121. DOI: https://doi.org/10.1111/j.1095-8339.2009.00996.x

Arizaga S, Ezcurra E. 1995. Insurance against reproductive failure in a semelparous plant: bulbil formation in Agave macroacantha flowering stalks. Oecologia 101: 329-334. DOI: https://doi.org/10.1007/ BF00328819

CIE [International Commission on Illumination]. 2004. Technical report Colorimetry. CIE 15. 3rd. Ed. 82 p. ISBN 3901906339 
Copeland LO, McDonald MB. 2001. Principles of Seed Science and Technology. Boston. MA: Springer. DOI: https://doi.org/10.1007/978-1-4615-1619-4. ISBN: 978-1-4615-1619-4

Cruz C, del Castillo L, Robert M, Ondarza RN. 1985. Biología y Aprovechamiento Integral del Henequén y otros Agaves. Centro de Investigación Científica de Yucatán, A. C.

Delgado-Lemus A, Casas A, Téllez O. 2014. Distribution, abundance and traditional management of $\mathrm{Aga}$ ve potatorum Zucc. in the Tehuacán Valley, Mexico: bases for sustainable use of non-timber forest products. Journal of Ethnobiology and Ethnomedicine 10: 1-12. DOI: https://doi.org/10.1186/17464269-10-63

Delouche JC, Wayne TS, Raspet M, Lienhard M. 1971. Prueba de Viabilidad de Semillas con Tetrazol. Buenos Aires, Argentina: CRAT, AID.

Enríquez del Valle JR. 2008. La Propagación y Crecimiento de Agaves. Oaxaca, México: Fundación Produce Oaxaca, A.C. e Instituto Tecnológico del Valle de Oaxaca.

Fragoso-Pérez EM, Gutiérrez-Hernández GF, Virgen-Vargas J. 2006. Repercusiones físicas y fisiológicas del envejecimiento natural de semillas de cruzas simples de maíz y sus líneas progenitoras. Revista Fitotecnia Mexicana 29: 75-80.

García-Herrera EJ, Méndez-Gallegos SJ, Talavera-Magaña D. 2010. El género Agave spp. en México: principales usos de importancia socioeconómica y agroecológica. Revista Salud Pública y Nutrición 5: 109-129.

García-Mendoza AJ. 2010. Revisión taxonómica del complejo Agave potatorum Zucc. (Agavaceae): nuevos taxa y neotipificación. Acta Botanica Mexicana 91: 71-93. DOI: https://doi.org/10.21829/ abm91.2010.292

Garrido JL, Rey PJ, Herrera CM. 2005. Fuentes de variación en el tamaño de la semilla de la herbácea perenne Helleborus foetidus L. (Ranunculaceae). Anales del Jardin Botánico de Madrid 62: 115-125. DOI: https://doi.org/10.3989/ajbm.2005.v62.i2.10

Gutiérrez-Hernández GF, Vázquez-Ramos JM, García-Ramírez E, Franco-Hernández MO, ArellanoVázquez JL, Durán-Hernández D. 2011. Efecto del envejecimiento artificial de semillas de maíces criollos azules en su germinación y huella genómica. Revista Fitotecnia Mexicana 34: 77-84.

ISTA [International Seed Testing Association]. 2015. International rules for seed testing. Bassersdorf, C. H. Zurich, Switzerland.

Maguire JD. 1962. Speed of germination-aid selection and evaluation for seedling emergence and vigor. Crop Science 2: 176-177. DOI: https://doi.org/10.2135/cropsci1962.0011183X000200020033x

Marcos-Filho J. 2015. Seed vigor testing: an overview of the past, present and future perspective. Scientia Agricola 72: 363-374. DOI: https://doi.org/10.1590/0103-9016-2015-0007

McGuire RG. 1992. Reporting of objective color measurements. HortScience 27: 1254-1255.

Padrón-Pereira CA, Padrón-León GM, Montes-Hernández AI, Oropeza-González RA. 2012. Determinación del color en epicarpio de tomates (Lycopersicum esculentum Mill.) con sistema de visión computarizada durante la maduración. Agronomía Costarricense 36: 97-111.

Ramírez-Tobías HM, Niño-Vázquez R, Aguirre-Rivera JR, Flores J, de Nova-Vázquez JA, Jarquín-Gálvez R. 2016. Seed viability and effect of temperature on germination of Agave angustifolia subsp. tequilana and A. mapisaga; two useful Agave species. Genetic Resources and Crop Evolution 63: 881-888. DOI: https://doi.org/10.1007/s10722-015-0291-x

Rangel-Landa S, Casas A, Dávila P. 2015. Facilitation of Agave potatorum Zucc.: An ecological approach for assisted population recovery. Forest Ecology and Management 347: 57-74. DOI: https://doi. org/10.1016/j.foreco.2015.03.003

SAS [Statistical Analysis System]. 2002. SAS Institute. Inc. Cary N. C., USA. Ver. 9.2.

Torres I, Casas A, Delgado-Lemus A, Rangel-Landa S. 2014. Aprovechamiento, demografía y establecimiento de Agave potatorum en el Valle de Tehuacán, México: Aportes ecológicos y etnobiológicos para su manejo sustentable. Zonas Áridas 15: 92-109.

Vadillo G, Suni M., Cano A. 2004. Viabilidad y germinación de semillas de Puya raimondii Harms (Bromeliaceae). Revista Peruana de Biología 11: 71-78.

Valenzuela-Zapata AG. 1994. El Agave Tequilero: Su Cultivo e Industrialización. Guadalajara, Jalisco, México Ed. Ágata. 119 p. ISBN: 10-9709132709.

Willan RL. 1991. Guía para la Manipulación de Semillas Forestales. Roma, Italia: Centro de Semillas Forestales de DANIDA, FAO. ISBN 92-5-302291-4. 